\title{
RESISTÊNCIA BICHA NA LITERATURA CTÔNICA DO LAMPIÃO DA ESQUINA
}

\section{QUEER RESISTANCE IN THE CHTONIC LITERATURE OF NEWSPAPER “LAMPIÃO DA ESQUINA"}

\author{
Rick Afonso-Rocha' \\ [https://orcid.org/0000-0001-5873-4136] \\ DOI: 10.30612/raido.v15i38.14583
}

RESUMO: Pretendo desenvolver o conceito de "Literatura ctônica", para adjetivar os textos publicados na coluna literária do Lampiâo da Esquina. Nesse sentido, seu valor transgressivo resulta do processo dialógico de recepçăo. Em minha leitura, essas literaturas habitavam uma zona de indeterminaçăo: nem a margem nem o centro. Habitavam o subterrâneo. O ctônico traduz-se em uma relaçâo agonística radical que expôe a ficcionalidade excludente da norma literária. Os sentidos fixados por ela "universalizam-se", de modo que apagam sua identidade e seu particularismo branco, cis, heterossexual, magro, urbano, cristăo, de classe. Todo o resto será julgado, criticado, valorado e excluído tendo por base a identidade ausente do "universal". Assim, interpreto a transgressăo lampiônica como uma possibilidade de sonhar, delirar concretamente a partir da resistência e da contestaçâo bicha.

Palavras-chave:LiteraturaLGBT+.Ditadura cis-hétero-militar.Literaturabicha.Resistência LGBT+.

ABSTRACT: I intend to elaborate on the concept of "Chtonic Literature", to characterize the texts published in the literary column of Brazilian newspaper "Lampiăo da Esquina". In this sense, its transgressive value results from the dialogic process of reception. In my reading, these literatures inhabited a zone of indeterminacy: neither the margin nor the center. They inhabited the underground. The chthonic translates into a radical agonistic relationship that exposes the exclusionary fictionality of the literary norm. The meanings fixed by it "become universal", so that they erase their identity and their white, cis, heterosexual, thin, urban, Christian, class identity. Everything else will be judged, criticized, valued and excluded based on the missing identity of the "universal". Thus, I interpret the "lampionic" transgression as a possibility of actual dreaming, fantasizing from the queer resistance and contestation.

Keywords: LGBT + Literature. Cisgender-straight-military dictatorship. Queer literature. LGBT + resistance.

1 Universidade Estadual de Santa Cruz (UESC). 


\section{LAMPIÃO LANÇA LUZES NAS ESQUINAS DA LITERATURA}

Já de início, ${ }^{2}$ gostaria de sinalizar que evito a utilizaçăo do termo "marginal" para adjetivar os textos literários publicados no Lampiâo da Esquina, visto que, como entendo, esse conceito é restritivo à poesia da década de 1970 (CABAN̂AS, 2005). Entretanto, também considero que, na época de circulaçấo do jornal (1978-1981), as literaturas ditas "homossexuais", termo utilizado no período para se referir às multiplicidades sexuais e de gênero, hoje abarcadas pela sigla LGBT $+{ }^{3}$ nâo se encontravam à margem, como faz supor o conceito, local ainda possível de ser visto e sobre os quais ainda era possível emergir enunciados.

Pensemos a margem como quadrante geográfico-espacial. Quando olhamos para uma folha de papel, visualizamos a margem, sabemos que ela está ali. A margem impóe sua presença anômala ao centro. E é também pela sua existência que o centro se define. Assim, digamos, a margem é a condiçăo de possibilidade da identidade ausente do centro. Dessa forma, constitui-se como o lugar indesejado pelo centro, mas necessário à sua constituiçăo, ao seu exterior constitutivo.

Logo, considerando as políticas sexuais e de gênero atuantes durante a ditadura cis-hétero-militar (AFONSO-ROCHA, 2018; 2020a; 2021) com a intensificaçăo e reforço, - por parte do governo militar e das instituiçôes intraestatais, - da matriz cisgênera e heterossexual, entendo que as literaturas bichas ${ }^{4}$ náo integravam a margem. Ao contrário, se encontravam no subterrâneo, longe, assim, do espectro de visibilidade e do campo de enunciabilidade que recortavam e (con)formavam a elite intelectual brasileira.

Considerando que o visível e o enunciável constituem os estratos das relaçōes formais de saber (DELEUZE, 2017), de modo que este entrecruzamento estabelece a distinçáo entre o que é possível ser visto e dito do que nâo é possível dizer e ver em determinada formaçăo histórica; compreendo que as literaturas bichas, como aqueles textos publicados na coluna literária do jornal Lampiâo da Esquina, habitavam, no período, uma zona de ilegibilidade. Significam, como leio, o impossível de ser visto ou dito e, portanto, lido, porque imaginariamente informulável naquelas condiçóes sócio-históricas de saber, recortadas pela homogeneidade ilusória da formaçăo histórica dominante.

Cabe destacar, contudo, que tal impossibilidade decorria, năo das condiçôes de visibilidade e enunciabilidade da formaçâo histórica em si, visto que tais sentidos já eram factíveis. Ainda que tivessem, como sustento, existência subterrânea, já era

2 Uma versâo preliminar deste trabalho foi publicada, em coautoria com meu orientador, André Luis Mitidieri, nesta mesma revista: (AFONSO-ROCHA; MITIDIERI, 2019).

3 Opto pela utilizaçăo da sigla reduzida LGBT+, por entender que é a forma mais usual e popularizada, como também por compreender que o sinal + visa a abarcar a multiplicidade de práticas, vivências, orientaçôes sexuais, identidades de gêneros que desviam da normalidade cisgênera e heterossexista. A sigla aqui é tomada, nâo como um rol taxativo, mas como um significante polissêmico que aponta para as existências que transitam e contestam à cis-hétero-realidade.

4 Por bicha, entendo uma relaçâo territorial de contestaçăo simbólica do imperativo cisgênero e heterossexual. Poderia ainda dizer que é uma reduçáo da formulaçáo bichasapatrans (maribollotrans), de Paco Vidarte (2019). O termo náo diz apenas daquelas existências homossexuais masculinas, mas sinaliza para as vidas animalizadas (bicha = verme intestinal, viado ou sapatáo que em sua forma mais usual torna-se sapa) e nâo assimiladas pela norma cissexista. Claro que essa náo-assimilaçáo é sempre circunstancial, nunca apriorística. Afinal, estamos todas a dançar com o poder. Ou, dito de outro modo, o poder é a própria dança. Nấo há resistência pura e sem contaminaçâo. Nâo há, da mesma parte, funcionamento do poder extrínseco à resistência. 
possível serem formulados, ditos e vistos. Dessa forma, o náo habitar a margem, isto é, sua ilegibilidade, decorria do funcionamento da censura. Essa pensada como modo anacrônico de calar o já-possível (MELO; BECK, 2019a; 2019b). Por censura, năo quero indicar apenas o mecanismo estatal de controle do dizer e do visível, personificado nos órgâos de segurança e informaçăo ou nas instituiçôes de controle moral, como a Divisăo de Censura de Diversóes Públicas (DCDP), responsável pela censura formal de inúmeros objetos culturais LGBT+ durante a ditadura cis-hétero-militar.

A censura, aqui, é considerada como funcionamento intraestatal, isto é, envolve a rede que se estabelece entre o dito e o năo-dito. Enquanto funcionamento, năo se restringe ao aparato estatal, ainda que tenha, como teve na ditadura, nesse aparato, seu suporte fático e formal. A censura aparece como o silêncio imposto a determinadas regiôes do dizível e do visível. Silêncio garantido e reforçado pelas relaçôes de poder dominantes. Assim sendo, evidentemente, devemos considerar que as instituiçôes desempenham papel singular nesse funcionamento. Pensemos na instituiçăo literária e em seu funcionamento canônico de estabelecimento do que é literário. O cânone, como norma, exclui, silencia e apaga textos outros que, por năo se inserirem na reprodutibilidade dominante, sâo produzidos como subliteraturas, literaturas menores ou manifestaçôes literárias. Tal funcionamento traduz-se como censura, isto é, como um modo de calar o possível.

A circulaçăo dos dizeres e visibilidades pressupóe o controle dos sentidos. Ainda que tais sentidos já possam ser formulados, inscrevendo-se nas condiçōes de factibilidade do dito e do visível em uma dada formaçâo histórica, o funcionamento anacrônico da censura interfere em sua circulaçăo. Enquanto a margem tem seu funcionamento regulado pela formaçâo histórica, considerada como regime de luz e de linguagem (DELEUZE, 2017), que produz sua homogeneidade ilusória, o subterrâneo obedece também ao funcionamento da censura, essa pensada como suplemento que repete, cita e desloca os sentidos possíveis.

Dessa forma, o valor transgressivo, resultante do processo dialógico de recepçáo, da literatura bicha publicada no jornal Lampiâo da Esquina (1978-1981) deve ser analisado tendo em questáo o contexto ditatorial de uma época na qual quem ousava dizer-se bicha, estaria exposta ao estigma, ao preconceito, como também à violência e ao risco de morte, - para dizer-se bicha era preciso, assim como Antígona, ser um parresiasta, gozar da coragem de verdade, assumindo o subterrâneo como espaço de contravisibilidade e contra-enunciabilidade:

O sujeito, ao dizer essa verdade que marca como sendo sua opiniăo, seu pensamento, sua crença, tem de assumir certo risco, risco que diz respeito a própria relaçăo que ele tem com a pessoa a quem se dirige. Para que haja parresia é preciso que, dizendo a verdade, se abra, se instaure e se enfrente o risco de ferir o outro, de deixá-lo com raiva e de suscitar de sua parte algumas condutas que podem ir até a mais extrema violência. (FOUCAULT, 2011, p. 39).

A partir dessas reflexōes, proponho o conceito de "Literatura ctônica" (AFONSOROCHA, 2021) para adjetivar os textos publicados na coluna literária do Lampiâo da Esquina. Isso porque, como já mencionei, tais literaturas habitavam uma zona de indeterminaçăo: nem a margem nem o centro. Esse espaço inaudito, silenciado e reiteradamente apagado é o subterrâneo ou o ctônico. Zona cuja suposta existência assombra e fascina a norma literária. Se a instituiçâo literária, em seu funcionamento canônico, 
produz o centro como o iminentemente literário e a margem como o subliterário que serve ao reforço do padrăo estético do cânone (a norma literária precisa ser confrontada com o anômalo, com o feio, para ter sua normalidade e superioridade reconhecidas), de modo que a margem se traduziria na anomia conservadora da normalidade estético-literária, o subterrâneo ou ctônico poria em jogo o próprio funcionamento binário centro-margem, constituindo o impossível de ser absorvido pela dinâmica conservatória da norma literária, cuja margem é, queiramos ou nâo, seu sustentáculo. Trata-se de recusar a normalidade, mesmo que ela esteja disfarçada de valor estético.

O ctônico traduz-se em uma relaçăo agonística radical que expōe a ficcionalidade excludente da norma literária, mostrando como essa ficcionalidade serve à fixaçáo de determinados sentidos, ao passo que silencia e impede sentidos outros. Como é possível supor, os sentidos fixados pela norma literária "universalizam-se", de modo que apagam sua identidade e seu particularismo branco, cis, heterossexual, magro, urbano, cristăo, de classe. Todo o resto será julgado, criticado, valorado e excluído tendo por base a identidade ausente do universal. Boa literatura, ou melhor, literatura será apenas aquela que percorre e perfaz o caminho imposto pela norma literária. As demais, subliteraturas. A funçăo destas é, na lógica binária, sustentar o valor estético do cânone. Afinal, só sabemos o que é uma boa literatura pela comparaçăo com textos menores. Aqui, incide o ctônico.

Isso porque, habitando uma zona de indistinçăo ontológica, estética, social e política, tais textos, pensados como emergências da relaçáo subterrânea, náo reclamam uma suposta "literariedade" como condiçăo de existência estético-literária. Por isso, afirmar que os textos subterrâneos săo literários é, em si, uma postura estratégica. Năo que esteja minimizando seus valores estéticos, muito pelo contrário. Contudo, esses textos só podem ser considerados literários como atitude provocativa, isso porque, em seu funcionamento sâo contra-literários, trepam nas engrenagens dos mecanismos de estabelecimento da literariedade, expondo que as supostas qualidades do que é ou năo literário săo artificiosamente projetadas para a manutençâo do status quo de relaçóes de poder dominantes. Como apontou Terry Eagleton (2003), a literatura é uma instituiçăo burguesa; acrescento: com recorte de gênero, raça, sexualidade, estética corporal e condiçôes socioeconômicas muito bem demarcados, ainda que apague seu particularismo hegemônico. Portanto, ser literário é, em alguma medida, ser subsumido ao padrăo heterocistemático, branco, masculino, urbano, após "minucioso confronto" com a norma literária. Dessa forma, tal epônimo é colocado em suspeita pela existência dos textos subterrâneos.

Habitar o subterrâneo é sempre uma circunstancialidade relacional, porque decorrente do jogo dialógico de leitura. Nâo há o ontologicamente subterrâneo. As condiçôes de legibilidade mudam, os sentidos derivam, a potência transgressiva pode ser assimilada pela integralizaçăo das subjetividades, o que resulta na entrada desses sentidos na dinâmica binária centro-margem. Evidentemente, a margem resiste e insiste contra o centro. Nâo desprezo isso. E, sustento que nem toda a margem é assimilada ou subsumida à norma literária. Alguns espaços da margem sâo ocupados, reivindicados à força, de modo a impor sua presença subterrânea pela margem na visibilidade e enunciabilidade dominante.

Desprezar aquilo que Michel Foucault (2017) denominou de polivalência de enunciabilidade (e também de visibilidade) seria incorrer no idealismo imaginário da pura resistência ou mera reproduçâo, como se determinadas literaturas, pensadas como homogeneidades, apenas reproduzissem os discursos e visibilidades dominantes, 
de modo a reforçar as opressóes e contradiçōes de gênero, raça, classe, de sexo etc., enquanto outras literaturas só "expressassem" sentidos de resistência às relaçôes de poder dominantes. Quando, em verdade, devido à polivalência constitutiva, tais materialidades reforçam, ao mesmo tempo que resistem aos padróes hegemônicos impostos. Pensamos as literaturas para além do marco expressionista, o que seria recolocar a problemática do autor consciente e da genialidade. Pensamo-las em seu funcionamento dinâmico, polivalente, contraditório e real. Elas nada expressam, espelham ou refletem; mas se inserem em determinados funcionamentos que podem reforçar ou fraturar as estruturas, uma vez que difratam os sentidos esperados, queridos, porque minunciosamente projetados por aquelas. As estruturas estăo aí, năo podemos fingir que as superamos. Para miná-las, precisamos nos haver com sua existência.

Em relaçăo aos textos publicados na coluna literária do Lampiâo da Esquina, tal indeterminaçấo decorria tanto da moralidade cis-heterocentrada quanto da suposta ausência de valores estéticos, afinal, tais autores năo teriam conseguido superar suas próprias vivências em direçăo aos temas universais (leia-se aos dramas do homem branco, cis, heterossexual, cristăo, urbano, de classe média, sudestino...). Nesse sentido, o silenciamento imposto pelas instituiçóes literária, cultural e acadêmica justificavase no suposto "particularismo identitário", e, portanto, de menor valor estético, presentes nesses textos, num claro desprezo das discussóes sobre recepçăo, leitura como processo dialógico etc., de modo a reedificar o império da textualidade traduzida pela ideia de que os sentidos sâo dados, colocados na forma material do texto pelo autor, sempre na direçăo da previalidade significante.

Some-se a este primeiro silenciamento, o imaginário reforçado pela crítica de que literatura é aquela publicada em livros, tendo como característica a perenidade. Assim, nesse imaginário, os textos publicados em jornais năo seriam verdadeiramente literaturas, com exceçâo do romance de folhetim publicado em jornais literários cujo leitor esperado era o especializado. Já os demais jornais, com colunas ditas literárias, serviam apenas à publicaçâo de pequenos textos de sujeitos desconhecidos ou, quando de autores reconhecidos, limitavam-se a recortar trechos de romances ou publicar crônicas, contos e outros gêneros lidos como menores; em muitos casos, publicavam textos de seus próprios leitores e assinantes. Naquele imaginário, sustentado pela e sustentante da instituiçâo literária normativa, a literatura, enquanto manifestaçăo do belo e do sublime, requereria suporte material adequado: o livro.

Algo que aparentemente parece banal, desvela-se extremamente útil à consagraçăo do cânone literário. A exigência do livro como suporte material da literatura revela-se como estratégia de retroalimentaçăo da canonicidade. Isso porque, como apontou Foucault (2015), a noçấo de livro serve à perpetuaçáo do projeto humanista de autor moderno, reatualizando a unidade e a continuidade como postura epistêmica. Projeto esse necessário ao funcionamento do cistema literário (AFONSO-ROCHA, 2021), assim grafado para marcar a dimensâo cissexista da instituiçâo literária.

Lançada ao subterrâneo, as literaturas bichas publicadas no Lampiâo, como interpreto, fizeram do subterrâneo sua potência dionisíaca para resistir, de tal modo a contestar "[...] o imaginário de gueto como um espaço de silenciamento: o gueto pode ser lido, parafrasticamente, como um lugar de discriminaçâo, de medo, de interdiçáo e censura" (MELO; BECK, 2019b, p. 154). Nessa direçâo, entendo que o ctônico intervém na memória do gueto, materializando sentidos outros para constituir o gueto como 
espaço de contestaçăo, espaço outro para aqueles impossíveis de serem assimilados. Sem, contudo, recair na caracterizaçăo do gueto como lócus identitário, "[...] isto é, espaço de contençáo da circulaçáo dos sentidos subversivos [...]; pelo chamado [...] para que dele saíssem; pela negaçăo do próprio gueto" (MELO; BECK, 2019b, p. 155). É aqui que compreendo o ctônico como ocupaçâo do significante, para radicalizar, tal qual leio naquela literatura publicada no Lampiâo, as imagens dos sujeitos cis-heterodissidentes como "[...] figura noturna, sombria, amaldiçoada e moralmente subversiva, metaforizada no sentido de degenerescência" (MELO; BECK, 2019b, p. 155).

Ctônico significa, na mitologia grega, "relativo à terra" e remete, conforme Michel Maffesoli (1996), aos deuses e espíritos do mundo subterrâneo ou telúrico, em oposiçâo aos deuses olímpicos, também denominadas uranianos - relativo ao céu. Por isso, símbolos da perfeiçấo, certeza e beleza. Enquanto os deuses uranianos "representam" o próprio símbolo, - aquilo que homogeneíza, une, mutila a diferença, -os deuses telúricos apresentam o diábolo: significando a pluralidade e o dissenso na/da diferença.

O conceito de literatura ctônica ou subterrânea alude, assim, às notaçôes culturais embebecidas no cotidiano, nas quais a verdade comparece como uma dimensâo ética, ligada ao cuidado de si, "uma verdade que nâo exige, para ser proclamada, uma firmeza de alma, uma tensâo ética, torna-se inútil e incerta" (GROS, 2004, p. 11). Dessa forma, sâo interrogadas as relaçóes de poder intrínsecas à significaçâo positiva de algumas práticas em detrimento de outras. $\mathrm{O}$ foco da narrativa sai, portanto, dos grandes acontecimentos e temas "universais" para os sujeitos e práticas do cotidiano. Ao realizar esse movimento, a literatura ctônica pode permitir a problematizaçăo do subterrâneo e, no mais das vezes, possibilitar outras significaçóes sobre o passado, escapando, assim, ao império da universalidade, aquela identidade que produz sua própria ausência.

Ctônica, pensada como lócus circunstancial, é a literatura que resiste à imaginária unicidade do real em sua ilusória hiper-realidade imposta. Como destaquei acima, resiste à própria noçăo de literatura, a qual assume como ressignificaçăo estratégica de subversăo. Nesse sentido, aproxima-se da embriaguez de Dioniso (NIETZSCHE, 2007), divindade que melhor congrega, na mitologia grega, as características telúricas, entidade sempre a transitar entre o sagrado e o profano. Como interpreto, a literatura do Lampiâo traduz-se em ctônica, visto que diluiu o Uno em uma interaçáo orgástica e orgasticamente coletiva, herética e profana: "O que o Ocidente reprime em sua visâo da natureza é o ctônico, que significa 'da terra' - mas das entranhas da terra, nâo da superfície [...] Săo as realidades ctônicas de que foge Apolo, o triturar cego da força subterrânea, o longo e lento sugar, a treva e a lama" (PAGLIA, 1990, p. 17).

\section{OS SUBTERRÂNEOS DA LITERATURA LAMPIÔNICA}

O Lampiâo da Esquina, jornal assumidamente "homossexual" que circulou durante a ditadura cis-hétero-militar brasileira, teve um total de 41 ediçôes, das quais 37 foram números ordinários, uma ediçăo inaugural ( $\left.n^{\circ} 0\right)$ e três números extraordinários. A coluna literária integrou somente 23 números. Algumas ediçōes apresentam duas seçôes literárias, uma destinada à poesia e outra à narrativa.

Identifiquei, nesses 23 números da revista, 50 textos literários, de 42 autores, a saber: Abelardo Castillo, Aguinaldo Silva, Álvaro de Campos, Antônio Botto, Antônio 
Roig, Augusto Frederico Schimidt, Cassandra Rios, Darcy Penteado, Fernando Gabeira, Fernando Wide, Franklin Jorge, Gasparino Damata, Gilmar de Carvalho, Glauco Mattoso, Harry Laus, Jean Genet, Joăo Carlos Rodrigues, Joăo do Rio, Joăo Gilberto Noll, Joáo Silvério Trevisan, José Louzeiro, José Renato Pimentel, Konstantínos Kaváfis, Leila Míccolis, Leopoldo Serram, M. Rocha, Manuel Puig, Maria Lucia de Barros Mott, Mário de Andrade, Mario Faustino, Mestre Therion, Moarcir de Moura, Olney Krüse, Paulo Augusto, Paulo Hecker Filho, Pedro Hilário, Políbio Alves, Renata Pallottini, Sosígenes Costa, Tony Pereira, Ulisses Tavares e Valério Pereliéchin ${ }^{5}$.

Passemos, entăo, à análise dos textos publicados na coluna "Literatura" do Lampiâo. Apresento, por amostragem, recortes das ediçôes publicadas em 1978, ano de surgimento do jornal, uma vez que, como leio, foi nesse período que o jornal melhor concretizou seu objetivo de contestar a produçăo da dissidência sexual e de gênero como inimiga da sociedade ${ }^{6}$, como forma de questionar a imaginarizada unidade do real em torno da cis-hétero-norma.

A ediçăo número zero trouxe três poemas de jovens poetas até entâo desconhecidos pelo grande público: Leila Míccolis, Franklin Jorge e Paulo Augusto. Os poemas têm como temática o amor e os afetos ctônicos, mas também a sexualidade e o ato sexual em si. Sâo poemas sujos, nâo eufeminizados, poeticamente vaginais, anais e fálicos por isso, naquele período, lidos como potencialmente transgressivos.

O poema de Paulo Augusto - "Na pensâo a flor de Minas" - é erótico7, direto, político e subversivo; ainda assim, conserva certa sutileza irônica ao questionar o regime de diferença sexual e de gênero intensificado pela "ditadura militar". ${ }^{8} \mathrm{O}$ universalista eu-lírico transmuta-se e convola-se em bicha-lírica ${ }^{9}$ em seu ousado desejo por "outro homem":

\author{
O rapaz do quarto 14 é rebento 24 anos, \\ da tradicional família mineira \\ Olhou nos meus olhos \\ um dia \\ seu pecado feito carne \\ e viu meus cílios baterem \\ Ele estremece,
}

foge o olhar - mas fala. Disse-me que tem muito medo

(AUGUSTO, 1978, p. 10).

5 Para um diagnóstico mais detalhado da coluna literária do Lampiāo, destacando suas configuraçôes socioeconômicas, de gênero, de classe, raciais, sexuais ver: (AFONSO-ROCHA, 2020b).

6 Sobre isso, ver minha reflexăo (AFONSO-ROCHA, 2020ㅎ․ 2021) a respeito da deimopolítica na ditadura cis-hétero-militar brasileira.

7 Erótico aqui é tomado como questionamento da realidade imposta como princípio de unidade, conforme Luís Warat (1988).

8 Aspeio para distanciar-me dessa nomenclatura que apaga a dimensăo cisgênera e heterossexual da ditadura brasileira. Em minha posiçâo: ditadura cis-hétero-militar (AFONSO-ROCHA, 2021).

9 Expressâo conceitual cunhada por Tales Pereira e André Mitidieri, segundo os quais: "a bicha-lírica compromete-se em ser porta voz dos falares marginais nos tempos da ditadura militar brasileira" (2018, p. 198). 
O poema de Augusto, como interpreto, tensiona uma situaçăo peculiar ocorrida em Minas Gerais. Antes mesmo da deflagraçăo do golpe militar de 1964, em Belo Horizonte, intensificava-se a perseguiçăo dos sujeitos cis-heterodissidentes, especificamente das travestis. O historiador Luiz Morando (2015) mostrou-nos o notório acirramento da produçâo do dissidente sexual e de gênero como inimigo social, nessa cidade, pelo menos desde 1961, com a ediçăo de leis e portarias estaduais utilizadas para embasar essa repressăo. Nesse caso, falo em repressăo entendendo que a produçăo dos sujeitos inscritos em práticas desviantes da cis-heteronormatividade se deu, no limite, pela repressấo, tendo-se em conta que toda repressâo já é um meio de produzir desde a sua base dis-positiva. Em outros termos, tanto o enunciado negativo "năo pode $\mathrm{x}$ " tem valor residualmente positivo, quanto o positivo "pode y" vale residualmente como negativo. Ou, como é possível ler na obra foucaultiana, a repressâo corresponde a um dos efeitos produtivos das relaçóes de poder.

Retornando ao poema de Paulo Augusto, penso que, devido à perseguiçăo de travestis em Belo Horizonte, o sintagma "tradicional família mineira" deve ser tensionado como referência ao conservadorismo do regime e às políticas sexuais e de gênero de intensificaçăo do cis-hétero-corpo como normalidade biológica. Nesse desenho contextual, diante do medo e nas teias do pecado, a bicha-lírica assume os prazeres mundanos, transcendendo os valores morais centralizados na "família" cristâ:

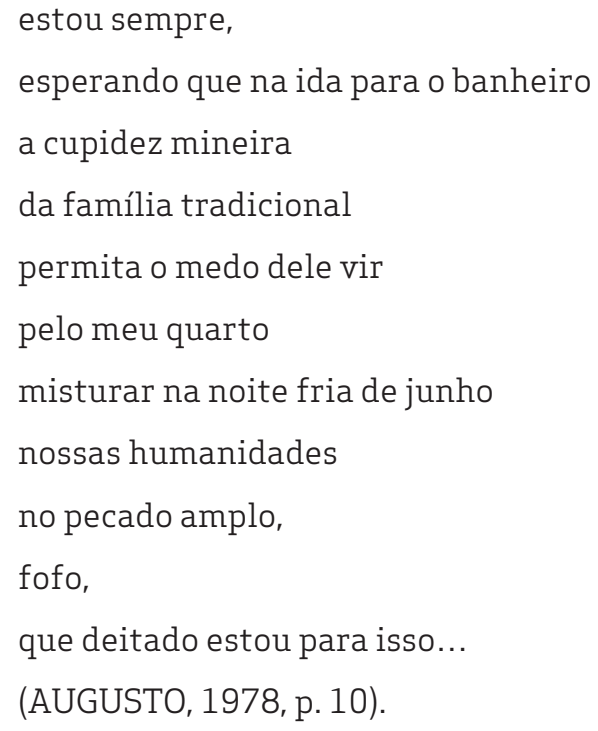

“O poema para teus seios", de Leila Míccolis, traduz-se como profanaçăo poética:

Cerro olhos pra náo ver,

e máos pra năo apalpar,

e bocas pra náo chupar

teus seios

(MÍCCOLIS, 1978, p. 10).

Tomo emprestada a reflexăo do filosofo italiano Giorgio Agamben (2005), segundo o qual, profanar possui sentido contra-dispositivo, que é o de retirar algo do uso restrito dos deuses e devolvê-lo ao uso comum do "povo". Assim, pensando na instituiçáo 
literária que, por muito tempo, foi o lugar do sublime e da perfeiçăo, consagrado aos deuses olímpicos, inacessível, portanto, ao subterrâneo, ao lamaçal cotidiano do "povo", essa entidade imaginária; seu caráter sacralizado castrou os desejos e silenciou os prazeres, apagando o sexo, amputando o corpo. Agora, profanada, a literatura bicha resiste e assume, de uma forma ou de outra, sua circunstancialidade tribal; atirada ao submundo, faz do subterrâneo a sua potência dionisíaca para resistir e insistir contra o binarismo reprodutor e garantidor da norma literária.

A bicha-lírica profana esse lugar estabelecido, para restituí-lo aos gozos, aos prazeres, às corporalidades e aos desejos, em movimento que se materializa num culto aos deuses ctônicos:

\author{
Desejo beber teu leite, \\ azeite de oliva branca, \\ e provar com minha língua \\ o macio do teu peito. \\ E se em inútil trabalho \\ te afasta a blusa de mim, \\ eu, por inúmeros meios, \\ cerro olhos para ver \\ e bocas para chupar \\ teus seios \\ (MÍCCOLIS, 1978, p. 10).
}

Leio o poema "Antropofagia", de Franklin Jorge, como um epinício ao prazer, personificado como realizaçáo espontânea da necessidade de comer, que é também uma forma de "fuder":

\author{
Conduzo-te faminto \\ até a velha cama, \\ que é grande e redonda \\ como uma mesa de banquete.
}

(JORGE, 1978, p. 10).

Pelo semântico, transfigura-se o desejo de comer com o uso da metáfora: o adjetivo faminto desloca-se da mesa para a cama; da comida para o corpo, o qual é, entăo, deliciado como banquete. A literatura bicha só poderia ser antropofágica, - num eterno ritual de foder corpos de deliciar-se entre cortes de bucetas, picas, peitos, cus... - , da cama grande para a glande minunciosamente lambida. A mesa de banquete póe em jogo o diábolo da cama pronta para o boquete. "Antropofagia" nos ensina a buscar o prazer de viver o gozo sem reprimi-lo, afinal, nossos corpos săo heterotopias antropofágicas:

Insalubres, nossas salivas

se confundem.

Rolam nossos corpus suados 
sobre as tenras cobertas.

Bates persistente

contra o meu umbigo

com teu sexo - peixe cego. Arrancando-te os pelos das axilas,

de pura agonia gozo

(JORGE, 1978, p. 10).

Nessa mesma ediçăo, foi publicado o conto "Aniversário", de Moacir de Moura. A narrativa tem como moldura a comemoraçăo do aniversário de um militar ("eu sentia o tecido áspero de sua farda contra minhas pernas") com seu amante masculino. A figura do militar inscrito em práticas de homossexualidades e vivenciando seus desejos bichas é alegórica, pois, além de questionar a castraçăo produzida pelo regime cis-hétero-militar, aponta para a desmitificaçăo da viril masculinidade militar: os fardados também trepam com o cu!

Diante da castraçáo do desejo maldito, o texto traz elementos indicativos da angústia vivida pelas personagens: "[...] eu senti o grande dia, e ele continuava sorrindo e seu sorriso, como o meu, era triste, e o ar do campo era leve" (MOURA, 1978, p. 16). A narrativa tem seu clímax quando da descoberta, pela família do militar, de sua viadagem: "a mulher, e a criança chorando e ele năo ligava, e ele gritava, a criança gritava e ela continuava em silêncio, e a criança continuava gritando e ela năo ligava, e eu olhei para ele, e ele havia esquecido de mim" (p. 16).

Contrastando com essa angústia, há, contudo, um ethos orgástico sentido em conjunto pelos amantes, intensificado pelo prazer do estar-junto, ainda que em circunstâncias adversas: "ele foi para trás de uma árvore, e gritamos nossos nomes alto, e o eco repetiu nossos nomes, e corremos"(MOURA, 1978, p. 16). Alusivamente, as personagens indicam que a vida deve ser vivida de maneira paroxística e emblemática aqui e agora, isto é, sinalizam que a vida merece ser vivida "apesar de". O desfecho da narrativa dá sinais da solidâo imposta aos sujeitos cis-heterodissidentes que, impedidos de viverem a completude de seus desejos e prazeres, sáo lançados numa vida antropófoba: "pediu novamente que eu me fosse, e năo cumpriu sua promessa e deixou-me para sempre agonizante como mosca nadando em óleo" (MOURA, 1978, p. 16).

Em maio de 1978, chegava às măos dos leitores a ediçăo $n^{0} 1$ do Lampiâo da Esquina cujo destaque foi o ensaio/entrevista "Confissóes de um Carmelita Descalço". O entrevistado, padre espanhol Antônio Roig, da Ordem dos Carmelitas Descalços, lançara, em 1977, o livro "Todos los parques no son un paraíso", em que se assumia bicha e reivindicava o direito de viver de acordo com a própria sexualidade, inclusive enquanto padre.

A coluna literária trouxe, na mesma ediçăo, um capítulo do livro de Antônio Roig, que havia resultado em sua suspensăo da igreja: "Nem todos os parques săo um paraíso". A estória se passa em Londres, lugar no qual o autor morou durante três anos e experimentou uma série de vivências importantes em torno de sua homossexualidade. A narrativa autobiográfica constrói a vivência bicha do autor-personagem em um parque inglês, provavelmente na década de 1960. Aqui, cabe destacar que, embora os países integrantes do Reino Unido fossem considerados democráticos, nesse período, manter relaçōes bichas era considerado crime na Inglaterra e no País de Gales até 1967; na Escócia, até 1980; na Irlanda do Norte, até 1982. 
O texto expóe que, mesmo sob o manto da democracia inglesa, a vontade soberana podia produzir, agora como tática de exceçâo, e náo mais como estado de excepcionalidade, o sujeito desviante da cis-heteronormatividade como homo sacer (AGAMBEN, 2007). No interior de uma "democracia consolidada", os desejos bichas eram criminalizados, o sujeito inscrito em práticas cis-heterodissidentes tornava-se marginalizado e destituído de sua condiçâo de cidadăo, lançado a viver uma vida sem importância, sem proteçăo jurídico-política.

Como sua vida năo tinha mais "peso", ou melhor, materialidade significante, quem o matasse náo teria cometido crime. 0 assim declarado homo sacer (homem sagrado ou abandonado) era lançado em uma zona de indeterminaçâo político-jurídica, isto é, sobre ele năo mais pairava a proteçăo do Estado de direito, sua vida estava nua, sem cobertura protetiva. Assim como Pôncio Pilatos, o soberano lava suas máos para se purificar do sangue reiteradamente derramado. No texto em análise, essa condiçâo de sacer é revelada quando "O homem de idade mediana e eu nos juntamos. Havíamos notado uma mútua atraçăo. Com precauçóes, começamos a nos beijar e logo a tocar um no outro" (ROIG, 1978, p. 16). Até que apareceu um homem mais jovem e se identificou como policial: "Terá que assumir sua responsabilidade por atos indecentes" (ROIG, 1978, p. 16). O policial passou a agredi-lo com socos e pontapés.

Por certo, a lei inglesa năo autorizava esse tipo de agressăo, mas como já discorrido, ao declarar um sujeito como homo sacer, a vontade soberana o transforma em vida à mercê; matá-lo náo é mais um crime, visto que já năo goza dos atributos que o qualificariam como ser humano. O homo sacer habita uma zona de indeterminaçăo ontológica: nem homem nem besta, apenas uma vida biológica comparável a um vírus, uma ameaça social. Por ser uma indeterminaçăo ontológica, essa vida gera desconfiança e produz o medo na "sociedade normal", devendo, assim, ser neutralizada (antropofagia) ou eliminada (antropoemia).

Quando a vontade soberana já náo mais pode declarar explicitamente um indivíduo como homo sacer, incentiva a produçáo dessa categoria por meio de táticas de exceçáo: criminalizando as práticas bichas, desqualificam-se os sujeitos que săo agenciados por elas. O policial agride porque sabe que a vontade soberana sustenta uma nâo-puniçâo. O Estado faz vista grossa, quando năo incentiva diretamente esse tipo de violência. A partir da aproximaçăo dessa significaçấo com a moldura espaço-temporal, ou seja, o contexto ditatorial do período, é possível afirmar que a escolha, ainda que năo consciente, do texto de Roig materializou-se como contestaçâo ao cis-hétero-militarismo que produzia as dissidências sexuais e de gênero como subjetividades mutiladas em torno da masculinidade e do corpo cis-heterossexual, o qual funcionou durante toda a ditadura e que ainda persiste numa tentativa de nunca acabar:

Com outro golpe me jogou no chăo. O lábio inferior começou a sangrar. Desta vez năo pude levantar. Tudo girava ao meu redor. Ele inclinou-se sobre mim e apropriou do meu porta-moedas. Quando afinal me levantou, me ameaçou. - 'Que eu năo volte a vê-lo por aqui, porque do contrário o matarei' (ROIG, 1978, p. 16).

Em 25 de junho de 1978, o Lampiāo publicava sua ediçăo nº 2. A coluna literária trazia "Do outro lado da porta", um texto de M. Rocha, que narra a rotina de um casal bicha. A narrativa apresenta alguns dos inconvenientes enfrentados por estes sujeitos: “Nunca pude entender direito as suas fugas repentinas no meio das festas. Procurava 
pensar que era pelo fato de uma claustrofobia social, mas quando regressava solitário para casa, concluía ser pelo estado de dúvida que o amargurava" (ROCHA, 1978, p. 8). O estado de dúvida, de vergonha, a fragilidade emocional, o estigma, tudo serve para fortificar o lugar social construído para sujeitos que ousam amar e, mais ainda, para os que ousam apenas gozar fora dos padróes cis-heteronormativos.

Na ausência de referências e de apoio moral, muitos cis-heterodissidentes năo suportam esse lócus de desprezo e de insignificância no qual sấo atirados: "Na primavera passada, sem dizer uma palavra, ele retirou a mala de dentro do armário e começou a jogar as peças de roupas com uma fúria incontrolável. [...] Corri até a janela ainda a tempo de vê-lo tomar o ônibus azul e acomodar-se na última poltrona" (ROCHA, 1978, p. 8).

Aqui, mais uma vez, a homossacralidade se faz presente: o lócus social de desprezo traduz, assim, os efeitos da declaração de homo sacer: o abandono. Potencializado por essa condiçáo, o abandono do companheiro pode, dessa forma, significar uma fuga de si, tentativa de viver longe do estigma e da vergonha. Abandono produzido nos contornos do regime cis-heteronormativo: abandona-se năo somente o outro, mas também, e sobretudo, a si mesmo, os seus desejos, a própria luta por si.

Para acentuar essa singularidade brasileira, elaborei o termo homossacralidade (AFONSO-ROCHA, 2020a), no sentido de que o risco potencial a que todos estaríamos submetidos, conforme Agamben (2007), em sermos declarados homo sacer, foi diariamente concretizado no regime cis-hétero-militar brasileiro quando direcionado às vidas bichas. $\mathrm{O}$ estilo e a ética de vidas bichas proclamaram-se "sagrados"; sujeitos cis-heterodissidentes, declarados descartáveis. A experiência ditatorial brasileira intraestatal particularizou a universalidade da figura do homo sacer, transfigurando-a no regime de sujeiçăo da homossacralidade ${ }^{10}$.

A imagem do homem cis-heterossexual é produzida simbolicamente como normal, de maneira que toda e qualquer tonalidade que nâo se espelhe nessa produçâo semiológica da realidade é atirada ao signo da anormalidade. A produçăo da sexualidade, dos desejos, dos sentimentos, dos afetos, e até das nossas açóes nâo escapam à cis-hétero-norma. Assim, para o sujeito cis-heterodissidente, cujos desejos e prazeres, de algum modo, ainda funcionam no espectro da política unidimensional, a vida sempre será vida mutilada, é sempre vida à mercê, fora do prazer, vida de castraçáo dos desejos, o lugar do vazio. Amar ou gozar para além dos prazeres oficiais torna-se o maior dos desafios, uma resistência que causa furor e engasgo ao ser exercida. Isso porque significa aderir a uma vida de abandono, uma vida ameaçadora, aquela zona de indistinçăo ontológica, política e jurídica, cujos habitantes devem ser contidos ou eliminados.

10 Nāo quero, com isso, negar outros fenômenos e dimensōes específicas da ditadura brasileira. A articulaçăo de variados e complexos regimes de sujeiçăo também intensificou a perseguiçấo contra negros, comunistas, mulheres, camponeses, todos lidos como inimigos sociais. Assim, a categoria homo sacer teria implicaçôes de gênero, por exemplo, negligenciadas por Agamben, como pontuou Ronit Lentin (2006), ao postular a mulher como femina sacra para acentuar que, em razăo da sua suposta funçấo como veículo de limpeza étnica (reproduçáo controlada) e à sua vulnerabilidade sexual, a vida mulher é uma vida à mercê do poder soberano: aquela que pode ser morta, engravidada, violentada, mas que náo pode ser sacrificada. Ou, como apontou Ewa Płonowska Ziarek (2008), embora os exemplos usados por Agamben de vida nua sejam recortados e diferenciados por questôes de raça, gênero, sexualidade e classe, sua análise acaba desprezando essa heterogeneidade, de modo a desconsiderar as configuraçôes de gênero, sexistas, coloniais e racistas da biopolítica na declaraçăo da sacralidade. 
O número 3 do jornal publicou o conto "O maricas", do escritor argentino Abelardo Castillo que, narrado pelo protagonista, dá conta de uma experiência compartilhada entre ele e César, amigo de infância. O jogo alusivo a Jorge Luís Borges, a partir do momento em que o narrador-personagem repete o nome do autor, instaura-se também por intermédio da narraçăo retrospectiva, como a simular uma nota autobiográfica nos meandros da ficçáo literária.

Mais especificamente, trata-se de uma confissăo da personagem central, claro que estilizada em sua narrativa breve: "Pois há coisas, palavras que a gente leva conosco como mordida, toda vida, mas uma noite sente que deve escrevê-la" (CASTILLO, 1978, p. 16). Conforme Foucault (2017), a confissâo foi colocada, pelo menos desde a Idade Média, como um dos rituais mais importantes dos quais se espera a produçáo da verdade. $\mathrm{O}$ ato confessional de Abelardo tem por objetivo aparente desculpar-se por um erro cometido no passado e libertá-lo da vergonha que veio a sentir por isso. O narrador- personagem busca o perdâo de César, por năo o ter defendido quando era insultado, aos gritos de "marica" e por ter se acovardado: "E dava vontade de gritar que todos nós juntos nâo valíamos a metade do que tu valias, mas naquele tempo a palavra era difícil e o riso fácil" (CASTILLO, 1978, p. 16).

A personagem central ainda deseja ser perdoada por năo ter tido como "expressar" que "te quis de fato, inexplicável e obscuramente". Assim, descreve o episódio resultante no afastamento entre os amigos, quando um dos amigos sugeriu que procurassem "uma gorda que cobra cinco pesos, vamos e já aproveitamos para fazer o machăo debutar, o César" (CASTILLO, 1978, p. 16). Abelardo enganou César para que fosse à casa dessa mulher, sem saber que os garotos planejavam suas iniciaçôes sexuais. Assustado, esse foge e Abelardo, após sair do quarto, vai ao seu encontro: "A măo me queimava, mas era necessário bater, machucar, sujar-te para esquecer aquela coisa como um orgulho que me afogava" (CASTILLO, 1978, p. 16). Antes de que o amigo vá embora, o narrador-personagem grita: "maricas de merda".

Após vários anos, Abelardo năo consegue se libertar da vergonha, tais palavras o devoram, queimam-no. Por isso, ele precisa se confessar: "Aquela noite, ao sair do quarto da gorda, eu lhe pedi que, por favor, năo contasse aos outros. Porque aquela noite eu năo pude. Eu também năo pude" (CASTILLO, 1978, p. 16). Para năo ser tachado de "maricas", a personagem renuncia aos seus desejos e prazeres.

A cis-heteronormatividade faz com que muitos de nós repitamos os passos da personagem: tornando-nos violentos com tudo aquilo capaz de nos lembrar que somos nós os diferentes ou que nos façam lembrar que nós também temos cu e que o cu é um espaço do desejo, ainda que reprimido. A sexualidade e o gênero do outro passam a ser, entâo, o nosso calcanhar de Aquiles, afinal, aponta para nossa vulnerabilidade. Por nos sentirmos incapazes, no mais das vezes, de suportar o estigma, a vergonha (im)posta ou pressuposta aos desviantes da cis-heteronormatividade, reforçamos o discurso do regime de diferença sexual e de gênero, até mesmo, atirando pedras em quem "desejamos inexplicável e obscuramente". Isso para que năo restem dúvidas quanto a nossa (frágil) masculinidade.

A tensāo trágico-erótica aparece nas lembranças de Abelardo, o qual implora para que César escute sua narrativa expiatória, em outro engenho que lembra a ficçăo borgiana, como de resto, outras narrativas literárias da modernidade, ao constituir 
a personagem como leitora e ao tratá-la como externa ao texto: “Escuta, César. É preciso que leias isto. Porque há coisas que se levam como mordidas, avivadas pela vergonha a vida inteira, há coisas pelas quais a gente sozinho se cospe na cara diante do espelho. Mas de repente, um dia, tem de dizê-las, confessá-las a alguém. Me escuta" (p. 16). Mais do que confessar sua homossexualidade (ainda que em tributo à cis-heterossexualidade), confessa seu acovardamento, suas castraçôes, suas limitaçōes, confessa-se um sujeito amputado.

A ediçâo n ${ }^{\circ} 4$ do Lampiâo, de agosto de 1978, publicou o texto "A dona boazuda", de Pedro Hilário, narrado por um operário, aparentemente da construçáo civil, que vive em uma cidade grande. Andando nas ruas, o rapaz vê uma mulher que desperta sua atençấo: "quando vi a tal boazuda parada ali naquela esquina me arrepiei que nem galo de briga e só faltei cair duro pra trás, no que ela atravessou a rua e fez um sinalzinho assim pra mim. Aí, que fiquei doído de vontade" (HILÁRIO, 1978, p. 16). Procuraram um local escondido para ficarem à vontade, de "desfrute, no achego, no cheiro. Comecei a dar beijos na dona pra deixar ela tonta e, quando já tava bem crespa de arrepio, eu ... zás! ..., arranquei a calcinha. Levei a mâo. Nem vấo acreditar no que eu segurei." (HILÁRIO, 1978, p. 16).

O operário demonstra sua frustraçâo ao perceber que a boazuda era uma travesti ou mulher trans. Como era possível tê-lo "enganado" assim? Diante desse "ultraje", o narrador-personagem resolve agredi-la: "Pois a boazuda era um tremendo de um macho igual a mim, que nem vocês mesmo. Ah, Ora que?! Dei lhe uma surra, bati pra valer, pra ensinar o safado a tomar vergonha na cara" (HILÁRIO, 1978, p. 16). Além da agressâo física, revelam-se procedimentos de violência simbólica, através da utilizaçăo de pronomes masculinos para se referir à travesti, evitando chamá-la de mulher: "é um macho". Bateu tanto que chegou a sentir remorso, teve pena daquela mulher que apenas chorava, sem reagir às agressóes. Supostamente "envergonhado" pelo que tinha feito, o narrador-personagem afirma:

Me arrependi de ver a tal de cabeça baixa, ajeitando a pulseira de figa, sem coragem de me olhar na cara, na certa, com receio de que eu começasse a bater de novo. Fiquei achando que eu tinha sido mau com ela, porque ela tinha se agradado de mim e me beijou e me chamou de 'amorzinho' (HILÁRIO, 1978, p. 16).

Após narrar que pediu perdăo e que tiveram, entăo, uma noite de sexo e afetos, o narrador-personagem desabafa, expondo novamente seus preconceitos:

Pra que tanto riso, heim? Náo văo me dizer que nunca frequentaram uma cabritinha, heim? Quando a gente tá a seco, qualquer cachaça serve... e a gente bem que gosta. Entăo, năo? E essa minha de ontem foi assim também. Eu tava necessitado, ela apareceu, eu quis, ela quis, a gente fez. Ué, e tem problema isso? Năo tem problema, nâo senhor. Os outros é que dizem que tem problema. (HILÁRIO, 1978, p. 16).

O operário demonstra viver um conflito intenso: sua agressăo marca o desejo obscuro que sentiu pela mulher; ele sabia que nâo houve engano, desejou-a ardentemente por ser quem era. Observemos como em seu discurso, ele animaliza a mulher, comparando-a uma cabrita. Numa clara estratégia de desumanizaçăo desses corpos. Nessa cis-narrativa, apenas o ponto de vista do operário é apresentado. A mulher trans é objetificada pelo narrador-personagem, que nâo a reconhece como igual. Nega-lhe o 
reconhecimento de humanidade. Por isso, agrediu-a, por ter-lhe "provocado" malditos desejos. Visualizo, nessa atitude, características transfóbicas, vez que se ridiculariza pessoas que desviam do imperativo cisgênero. Embora supostamente se arrependa de tê-la agredido, o narrador-personagem se refere à mulher trans com desdém: "a tal", "quem nunca frequentou uma cabritinha". E, sente a necessidade de se justificar pelo ocorrido: "qualquer cachaça serve", "Eu estava necessitado, ela apareceu, eu quis, ela quis, a gente fez". Importante sinalizar que, nesse momento de mea culpa e de tentativa de justificar sua atraçâo, ele volta a tratar à mulher no feminino: "ela quis".

O texto de Hilário denuncia a invisibilidade das pautas, reivindicaçóes, interesses da populaçâo trans: "Se é verdade que o Estado pode se apropriar das vidas, transformando-as em zoé (mera existência biológica), com as vidas trans, há singularidades. Náo se trata aqui de vidas sacrificáveis, mas de vidas reiteradamente sacrificadas. A potência anunciada transforma-se em política" (BENTO, 2017, p. 264). Inviabilizadas pelo movimento mainstream que teima em se autoproclamar "movimento gay", as subjetividades trans săo duplamente vitimizadas. Sob o signo "gay", escondem-se táticas que buscam homogeneizar a diferença. "Somos todos uma família" traduz muito bem essa colonizaçăo do subterrâneo.

Na contracorrente da homogeneizaçăo assim estabelecida, a literatura lésbica apareceu na ediçăo $n^{0} 5$ do jornal. Cassandra Rios escolheu o texto "A hora do amor", integrante do livro A santa vaca, entăo inédito, publicado em 1978. Devo pontuar que Cassandra foi a escritora mais censurada pelo regime cis-hétero-militar, de acordo com a Comissăo Nacional da Verdade (2014). Conforme Rick Santos, ao "re(a) presentar" subjetividades lésbicas em sua literatura, Cassandra propôs "um desafio enorme à visăo dominante e monolítica que cristaliza homossexuais como objetos do seu olhar" (2012, p. 20).

Leio este texto como significante alarido, repleto de prazeres, temores, clamores. A promiscuidade desnuda-se em suas palavras e é reclamada como territorialidade vaginal do gozo latente: "minhas măos alisavam meu corpo e meus dedos burilavam os bicos dos meus seios para masturbar-me sequiosa e incapaz de impedir ou frear os impulsos de um desejo mais forte do que a razăo" (RIOS, 1978, p. 16).

A literatura de Cassandra situa-se como signo de subversăo, aqui considerada como resultado do jogo dialógico de leitura, isto é, sua sublevaçâo desvela-se como efeito interpretativo. Por questionar os valores e a moral canônica, de modo a possibilitar leituras contra-hegemônicas, centradas nos desejos e no gozo das mulheres lésbicas, propondo, com isso, rasuras na "pornografia autoritária" (WARAT, 1988) ${ }^{11}$, a literatura de Cassandra foi lida como imoral.

Ao significar o desejo, o gozo e o prazer lésbico, Cassandra rejeitou o "lugar" estereotipado de o "homossexual" como ser sombrio, sofredor, vítima passiva da sociedade, suas personagens "[...] săo sujeitos resistentes tomando decisóes sob as restriçôes de um sistema de opressâo institucionalizada" (SANTOS, 2012. p. 26). Há nessa literatura,

11 Para Luís Alberto Warat (1988), em Manifesto do Surrealismo jurídico, a pornografia procura ansiosamente um princípio unitário. Assim, pornográfico é o cistema, para usar conceito de Viviane Vergueiro Simakawa (2015), que castra as possibilidades de sonhar, amputando a multiplicidade de transformaçóes. 
mais uma vez, considerada como efeito da interpretaçăo, uma transgressăo ctônica que resiste à imaginária realidade unidimensional, às representaçōes que constroem "um mundo verdadeiro das coisas de mentira", para usar a expressâo de Sandra Pesavento (2002), limitado, circunscrito aos valores burgueses de cariz judaico-cristă. Uma das estratégias de manutençăo da pornografia autoritária é a eliminaçăo das diferenças, da multiplicidade e o apagamento da derivaçăo de sentidos pela homogeneidade imaginária. Năo é à toa que o cânone literário, e o histográfico também, foquem, quase que exclusivamente, no homem, branco, burguês, urbano, magro, cis-heterossexual, ocidental e cristăo.

Ao contemplar uma figura feminina, o texto "As aventuras de Carmen Miranda", de Gilmar de Carvalho, publicado no ${ }^{\circ} 6$ do Lampiâo, de novembro de 1978, apresenta trechos da Carta-Testamento deixada por Getúlio Vargas: 'Cada gota de meu sangue será uma chama imortal à vossa consciência que manterá a vibraçăo sagrada para a resistência" (CARVALHO, 1978, p. 16). Tais passagens sâo entrecruzadas por um poema que enaltece a figura da cantora:

\author{
Carmem Miranda urna glória nacional bis \\ Carmem Miranda sambista sem rival \\ Fez do nosso samba uma bandeira \\ Embaixatriz da arte tropical \\ Subiu desde logo na carreira \\ Foi estrela universal. \\ (CARVALHO, 1978, p. 16).
}

A emblemática figura da cantora mantém relaçăo direta com a história das homossexualidades no Brasil no século XX, conforme destacou Green (2000, p. 21):
Em 1938, a cantora popular Carmen Miranda estrelava o filme brasileiro Banana da terra [...] Logo depois, durante os quatro dias de festas do carnaval, centenas de homens tomaram as ruas do Rio de Janeiro. Vestidos com saias brancas rodadas e turbantes limpos e reluzentes, como faziam as famosas mulheres da Bahia, esses homens excederam a própria paródia da baiana encenada por Carmen Miranda.

O texto resgata essa memória, das “falsas baianas à la Carmen Miranda [que] engajaram-se numa subversáo festiva que arremedava tanto o comportamento sexual normativo quanto o tradicional hábito de travestir-se durante o carnaval" (GREEN, 2000, p. 22). A cantora tornou-se diábolo da cultura bicha, tendo sua imagem extravagante recriada por sujeitos cis-heterodissidentes em todo o mundo. Carmen Miranda foi alçada ao posto de musa brasileira da viadagem, de modo que sua imagem se transmutou em signo da ambiguidade sexual, do camp ${ }^{12}$. Como afirmou Joâo Silvério Trevisan (2018, p. 371):

Carmen Miranda construiu seu próprio jeito de ser travesti de si mesma. Náo me parece casual, portanto, que entre homossexuais do mundo todo ela tenha se tornado um mito icônico, quer dizer, um símbolo da cultura da máscara - comum

12 "Comocomportamento, o camp pode ser comparadaà fechaçáo, à atitude exagerada de certos homossexuais, ou simplesmente à afetaçăo. Já como questão estética, o camp estaria mais na esfera do brega assumido, sem culpas, tăo presente nos exageros de muitos dos ícones da MPB". (LOPES, 2002, p. 95). 
no meio homossexual, em que a máscara pode ser tăo necessária para se proteger quanto para se impor. Quando de sua vinda ao Brasil, em 1996, a famosa drag queen americana RuPaul fez questăo de declarar: 'Eu sou filha de Carmen Miranda'. Por motivo semelhante, o Festival Internacional de Filmes Gay, de Turim, tomou a cantora brasileira como o centro de suas homenagens, em 1997.

Já a figura de Getúlio Vargas recorta a memória e a história das homossexualidades no Brasil pelo espectro do controle social. Foi durante o governo Vargas que a Polícia Civil, por meio do médico Leonídio Ribeiro, iniciou estudos antropológicos sobre homossexuais e travestis. Ribeiro procurou demonstrar as relaçôes entre a homossexualidade masculina e o mal funcionamento endócrino.

A subversăo manifesta-se por meio da tensâo entre a imagem recriada de Carmen Miranda, em referência à ambiguidade sexual, e a imagem de Vargas, em alusăo à política de intensificaçăo da cis-hétero-norma por meio da matriz médico-psiquiátrica, de maneira a produzir a reescritura ou a rasura: Getúlio Miranda ou Carmen Vargas. Vargas, entăo "responsável" por facilitar o estudo do comportamento desviante, é reescriturado na imagem da cantora: "Carmen Miranda é musa do PTB"13, finaliza.

Por fim, a última ediçâo do Lampiâo da Esquina do ano de 1978, publicada no mês de dezembro, trouxe trechos do romance $O$ beijo da mulher aranha, do escritor argentino Manuel Puig. Pelos segmentos publicados, é possível identificar um diálogo entre dois prisioneiros, Molina e Valentim. Năo fica claro, nesse fragmento, se Molina é uma travesti, visto que os trechos se alternam em designá-la como mulher e como homossexual masculino.

A narrativa foca na vivência amoroso-afetiva das personagens. Os diálogos mostram a preocupaçáo de Valentim por Molina: "Entăo me escute, que em alguma coisa poderei ajudar. É questăo de falar. Antes de tudo tem que pensar em pertencer a um grupo, em năo ficar só." (PUIG, 1978, p. 16); o medo de Molina em ser separada do amante: " $E$ do que tenho mais medo é de que nos separem e me ponham em outra cela e eu fique aqui para sempre, sabe lá com que otário." (PUIG, 1978, p. 16). Os excertos significam o cuidado entre os amantes: "quero que saia contente, e tenha boas recordaçôes de mim, como eu de você." (PUIG, 1978, p. 16).

O romance foi publicado em 1976, período conturbado da história argentina cuja "ditadura militar" tinha acabado em 1973. Em 1976, porém, a direita engendrou um golpe para derrubar a presidente Isabel Perón. Em seu lugar, instalou-se uma junta militar, chefiada pelo general golpista Jorge Rafael Videla. Durante o governo de Videla, opositores políticos foram presos, torturados e assassinados. A ditadura argentina também intensificou o dispositivo de produçáo que atuou sobre os sujeitos cis-heterodissidentes ${ }^{14}$.

Na narrativa, Valentim é um preso político, marxista; Molina foi presa por supostamente "corromper menores". Lembro-lhes que, durante a ditadura brasileira,

13 O Partido Trabalhista Brasileiro - PTB foi fundado por Getúlio Vargas em 1945.

14 Afirmo isso com base na leitura de Rapisardi e Modarelli (2001) sobre as vivências clandestinas dos "homossexuais" argentinos diante da "ditadura militar" (1976-1983). Muitas das ditaduras latinoamericanas, como Paraguai, Argentina e Equador, também tiveram intensificaçáo do regime de diferenças sexuais e de gênero com morte e perseguiçăo de LGBT+. 
a indeterminaçăo de conceitos jurídicos como "corrupçâo de menores" e "vadiagem" serviu a justificaçấo de inúmeras medidas persecutórias direcionadas aos sujeitos desviantes da cis-heteronormatividade, a exemplo de Molina. Como inexistia, na prática, uma norma criminalizando os sujeitos cis-heterodissidentes, o aparato policial-jurídico promovia a puniçâo desses por meio do seu enquadramento em tipos penais abstratos e vagos. Ou, como também era rotineiro, por açôes extralegais, como prisôes arbitrárias, desaparecimentos, extorsōes, batidas policiais em zonas de socialidade LGBT+, agressōes físicas, tortura, demissōes, exposiçăo a situaçōes humilhantes etc.

O encontro entre Molina e Valentim significa resistência aos regimes cis-héteromilitares brasileiro e argentino. Diante dos horrores vividos na prisăo, Molina ousava encontrar afeto (e sexo) em "outro" homem; o gozo clandestino insistia. Ironicamente, na prisâo em que é lançada por ser um sujeito desviante, Molina vivencia o amor e o sexo marginal: "Valentim, você e mamáe sâo as duas pessoas que eu mais quis no mundo." (PUIG, 1978, p. 16).

Outra questăo que pode ser levantada, a partir da narrativa, é a perturbada relaçăo entre a esquerda e as dissidências sexuais e de gênero. Militantes LGBT+ daquele período, a exemplo de Joáo Silvério Trevisan (2018), James Green (2000) e Herbert Daniel (1982), relataram que a esquerda era homofóbica e via as "homossexualidades" como desvio pequeno burguês, no caminho (im)posto pelos ideais maculados da Revoluçăo Russa a partir do golpe dado por Josef Stalin. As dissidências sexuais e de gênero eram indesejadas, nos grupos de esquerda, em razăo de esses entenderem que năo passava de um desbunde, náo condizente com a masculinidade revolucionária à la Che Guevara.

Essa imagem que a esquerda produzia dos sujeitos cis-heterodissidentes persistiu inclusive durante maio de 1968, como relatou Guy Hocquenghem (1980). Naquela época, entusiasmado com os ares de contestaçăo, alguns de seus colegas tentaram criar um Comitê de Açâo Pederástica na ocupaçăo de Sorbonne, para isso, rodaram panfletos e produziram alguns cartazes que foram espalhados pelo campus. No dia seguinte, os cartazes tinham sido destruídos, pois aquela atuaçăo pederástica despertara o incômodo e desconforto do Comitê central de ocupaçăo de Sorbonne, de orientaçáo marxista, por temer que a presença dos homossexuais poderia "desconsiderar o movimento". Noutro episódio, Hocquenghem (1980) conta-nos que uma das facçōes juvenis do Partido Comunista francês atacou o grupo do qual fazia parte, outra facçăo do PC, acusando-os de serem uma organizaçáo pequeno-burguesa, visto que existia homossexuais em suas fileiras, em referência a Hocquenghem, que a época năo era uma bicha assumida, fato que levou ao questionamento por parte dos seus companheiros: "você nâo é bicha, nâo é mesmo?".

Diante disso, penso que o encontro carnal entre Molina e Valentim significa também resistência à esquerda homofóbica brasileira e argentina.

\section{RESISTÊNCIA BICHA}

Quando o Lampiāo trouxe, em sua coluna literária, personagens cujas vivências, bem como as condutas, as práticas, os prazeres e os desejos tensionaram a normalidade 
cis-heteronormativa, questionou e afrontou a legitimidade moral imposta pelo regime ditatorial. A literatura lampiônica inaugurou uma autêntica resistência à cis-héteroditadura por meio da poesia, do erótico, da imagem, da magia, dos afetos, dos desejos, dos sonhos, do sexo, da crueza da vergonha.

No domínio do gênero e da sexualidade, da moral e dos bons costumes, a literatura bicha publicada no jornal mostrou que a cis-hétero-realidade năo passa de um conjunto de ficçóes apresentadas como naturais, que castram prazeres e gozos, limitando nossa capacidade de sonhar.

Assim, os textos aqui analisados, do referido jornal, constituem um processo de resistência ao totalitarismo e às práticas de dominaçăo disciplinar. Sustento que o Lampiâo foi um desses gestos de afirmaçăo da resistência frente a uma ordem sociocultural e politicamente totalitária. A literatura bicha publicada pelo jornal transmutou-se, assim, numa dimensăo do espaço público: "Estou me referindo ao espaço público como lugar de produçấo coletiva do desejo e das significaçôes. Um lugar onde o exercício dos poderes sociais se enfrenta com as forças que lhes resistem" (WARAT, 1988, p. 71).

O Lampiâo afigura-se como exercício do contra-direito de resistência bicha, visto que se apresenta como uma ruptura na ordem constituída que pôs em crise o sistema e a sociedade pelo simples fato de produzir-se (BOBBIO, 2004), configurando-se como ato de desobediência civil e espaço de contestaçăo bicha, por aguçar um ethos constituído a partir de emoçōes, sentimentos, sofrimentos e afetos partilhados em comum por sujeitos inscritos em práticas lidas como ameaçadoras. Nesse sentido, faz-se oportuno destacar que Norberto Bobbio (2004) entendeu que nâo se trataria de discutir sobre o caráter lícito ou ilícito da resistência em suas diversas formas, isto é, a problemática da resistência năo é colocada em termos jurídicos.

Embora superficialmente "ilícitas", tais notas de resistência constroem sua própria legitimidade, visto que năo buscam o reconhecimento jurídico e político da ordem cis-heterocentrada, cujo fundamento se edifica no estado de ameaça permanente (aceitamos a autoridade, porque tememos o outro), o que implica percebê-las como eficaz fundamento "extrajurídico", - pensado em sentido amplo -, para exercer o contra-direito de resistência bicha. Nesse sentido, faz-se oportuno destacar que Norberto Bobbio (2004) entendeu que náo se trataria de discutir sobre o caráter lícito ou ilícito da resistência em suas diversas formas, isto é, a problemática da resistência năo é colocada em termos jurídicos.

Ainda, conforme Bobbio (2004), a questâo do poder engloba a resistência, porque resistir é defender-se contra as relaçōes de poder dominante, uma forma de oposiçâo extralegal - com relaçăo ao modo como é exercida; e deslegitimadora - com relaçáo ao objetivo final. $\mathrm{O}$ autor distingue a resistência da contestaçâo, adotando, para isso, o critério da referência ao seu respectivo contrário: a obediência é o contrário da resistência, o contrário da contestaçăo é a aceitaçăo. Há uma leve, mas importante diferença entre a obediência a uma norma ou ao ordenamento e sua aceitaçáo. Enquanto obedecer é uma atitude passiva, aceitar é ativa: "implica, se năo um juízo de aprovaçâo, pelo menos uma inclinaçáo favorável a se servir da norma ou das normas para guiar a própria conduta e para condenar a conduta de quem năo se conforma com ela ou elas" (BOBBIO, 2004, p. 61). 
Resistir é todo comportamento de ruptura contra a ordem estabelecida, (im)posta. $\mathrm{O}$ ato de resistência póe em crise o sistema pela sua mera produçăo. Assim, leio o Lampiâo, sobretudo sua coluna literária, como comportamento de ruptura contra a ordem sexual e de gênero imposta pela ditadura cis-hétero-militar, mas também como espaço de contestaçăo, que é, para Bobbio, mais do que um comportamento de ruptura: refere-se a uma atitude crítica que póe a ordem estabelecida em questâo, sem necessariamente colocá-la em crise. A contestaçâo atinge mais do que os subsistemas político e jurídico, abrangendo modelos culturais gerais, tensionando a legitimidade profunda que assegura os subsistemas político e jurídico.

É essa a materialidade do que estou chamando de contra-direito de resistência. Nem a obediência nem a aceitaçăo da cis-hétero-norma. Assim, a literatura lampiônica, pensada como circunstancialidade ctônica, é tanto um comportamento de ruptura, de desobediência em relaçấo à ordem sexual e de gênero imposta pela ditadura cis-hétero-militar, como também um espaço de contestaçăo, de nâo-aceitaçâo da cis-hétero-norma.

\section{APAGARAM-SE AS LUZES DO LAMPIÃO?}

A literatura bicha publicada no Lampiâo da Esquina, pensada como efeito de leitura circunstancialmente delimitado, manifestou a revanche do "dionisíaco", da fugacidade do vínculo social. O periódico foi, portanto, uma declaraçâao de guerra à moral e aos bons costumes judaico-cristấos.

Por intermédio da literatura bicha, o Lampiâo operou um deslocamento da homogeneidade para a heterogeneidade do real, do pornográfico para o erótico (WARAT, 1988) resistindo à hiper-realidade totalitária. Dessa forma, potencializou o tribalismo de conotaçấo viada, constituído por pessoas que se identificam por meio de rituais, elementos de cultura, valores, moda, estilo, sentimentos, emoçôes, sofrimentos, medos, angústias e que, mediante essa socialidade, contestam e resistem ao individualismo e à identidade (MAFFESOLI, 1987).

Entendida para além das práticas sexuais entre sujeitos do mesmo sexo, compreendendo atitudes, gestos, afetos, sensibilidade, sentimentos, emoçôes, linguagem corporal, que infringem as normas rígidas pré-estabelecidas como masculinas/femininas ou transitem entre o masculino e feminino, a viadagem ctônica foi lida como imoral, uma afronta à ordem deimocrática cristă. Conceito derivado da noçấo de deimopolítica (AFONSO-ROCHA, 2018), essa última pensada como paradigma de governamento pelo medo (Deimos = deus grego do pânico e do medo generalizado), com a necessária produçâo de subjetividades amedrontadas e monstruosidades ameaçadoras, para a constituiçâo imaginária do fundamento da autoridade e a consequente perpetuaçâo das instituiçóes de integralizaçăo das relaçôes de poder dominantes. Nesse sentido, vejo a democracia como deimocracia, isto é, o governo do e pelo medo, cuja funcionalidade e permanência se sustentam no estado de risco permanente ("estamos em risco") e na marcaçăo/produçăo dos inimigos sociais.

O Lampiâo foi, dessa forma, "a batalha do sujeito pelo [contra-]direito de se colocar, de nâo aceitar a coerçăo, [de desobedecer, traduzindo] a batalha por um lugar no qual o sujeito encontre um poder de dizer, com ou sem respaldo da hierarquia" (LAGAZZI, 
1988). Trata-se da potência societal sobre a qual nos falou Maffesoli (2012, p. 12): uma "força interna precedente e fundante do poder em suas diversas formas". Excitados, vemos uma viadagem ctônica e tribal nas páginas literárias do Lampiāo.

Por isso, entendo que a literatura publicada nesse jornal aponta, năo para uma concepçăo de tempo linear ou cíclico, mas sim, para um tempo pontilhista ${ }^{15}$ : os pontos aparecem e se conectam com nosso passado e futuro, presentificando-os. Dessa forma, o tempo seria uma sucessâo de presentes, significando rupturas e descontinuidades. Essa transformaçáo sobre a percepçâo do tempo mostra que a ditadura nâo ficou no nosso passado; queríamos que assim fosse.

Como destacou Umberto Eco (2002), o fascismo é eterno porque se presentifica por meios dos pontos temporais que nos conectam ao passado e se projetam como futuro. Por isso, sempre será presente, ao menos em potência: "pode voltar sob as vestes mais inocentes. Nosso dever é desmascará-lo e apontar o indicador para cada uma de suas novas formas - a cada dia, em cada lugar do mundo (ECO, 2002, p. 10). Também pode trajar-se com vestes civis, e tem mostrado que convive bem com nossa deimocracia (AFONSO-ROCHA, 2021), pois é um dos seus efeitos. O tempo pontilhista mostra, da mesma forma, que o fogo lampiônico náo ficou preso no passado, mas comparece no presente para resistir e lembrar que "vencereis pero no convencereis"16.

É o eterno retorno do contra-direito de sonhar, de năo aceitar esquecer, nos tempos de "amnésia obrigatória", de contestar a pornografia autoritária. El derecho al delírio -, como disse Eduardo Galeano (1998). Aí está a transgressâo lampiônica, que nos permitiu sonhar, delirar concretamente a partir da resistência e da contestaçăo bicha, mostrando-nos que "A perfeiçâo seguirá sendo o privilégio tedioso dos deuses, mas neste mundo, neste mundo avacalhado e maldito, cada noite será vivida como se fosse a última e cada dia como se fosse o primeiro" (GALEANO, 1998, p. 34).

15 A noçấo de tempo pontilhista é desenvolvida por Maffesoli (2003) e retomada por Zygmunt Bauman (2008): "Tal como experimentado por seus membros, o tempo na sociedade moderna nâo é cíclico nem linear como costumava ser para os membros de outras sociedades. Em vez disso, para usar a metáfora de Michael Maffesoli, é 'pontilhista', um tempo pontuado, marcado (senâo mais) pela profusâo de rupturas e descontinuidades... A vida, seja individual ou social, năo passa de uma sucessấo de presentes, uma coleçâo de momentos experimentados em intensidades variadas." (p. 36).

16 Famosa frase dita por Miguel de Unamuno a José Millán-Astray, general franquista (PEDRÓS GASCÓN, 2007). 


\section{REFERÊNCIAS}

AFONSO-ROCHA, Rick. Bichas inauguram a utopia. Trabalho de conclusăo de curso (Bacharelado em direito) - Universidade Estadual de Santa Cruz, Ilhéus, Bahia, 2018.

AFONSO-ROCHA, Rick. Bichas também sangram: deimopolítica e direito de resistência na literatura "homossexual" do jornal Lampiâo da Esquina. Dissertaçăo (Mestrado em Letras: Linguagens e Representaçôes) - Universidade Estadual de Santa Cruz, Ilhéus, Bahia, 2020a.

AFONSO-ROCHA, Rick. 0 perigo cor-de-rosa: ensaios sobre deimopolítica. Salvador: Devires, 2021. (No prelo).

AFONSO-ROCHA, Rick. Um lampiăo ilumina as esquinas da literatura. Itinerários: Revista de Literatura, n. 50, p. 57-82, 2020b.

AFONSO-ROCHA, Rick; MITIDIERI, André Luis. Bichas inauguram a utopia: resistência homoerótica na literatura lampiônica. Raído, v. 13, n. 32, p. 47-72, 2019.

AGAMBEN, G. Homo Sacer: o poder soberano e a vida nua. Belo Horizonte: Editora da UFMG, 2007.

AGAMBEN, G. O que é um dispositivo? Outra Travessia, n. 5, p. 9-16, 2005.

AUGUSTO, P. Na pensâo a flor de Minas. Lampiăo da Esquina. Rio de Janeiro, nº 0, abr. 1978, Seçăo literária.

BAUMAN, Z. Vida para consumo: a transformaçăo das pessoas em mercadoria. Zahar, 2008.

BENTO, B. Transviad@s: gênero, sexualidade e direitos humanos. EDUFBA, 2017.

BOBBIO, N. Era dos direitos. Elsevier Brasil, 2004.

BRASIL. Comissāo Nacional da Verdade. Ditadura e homossexualidades. Brasília: CNV, 2014.

CABANAS, T. A poesia marginal e os novos impasses da comunicaçâo poética. Revista de Letras, v. 45, n. 1, p. 89-116, 2005.

CARVALHO, G. de. As aventuras de Carmen Miranda. Lampiăo da Esquina. Rio de Janeiro, nº 5, nov. 1978, Seçáo literária.

CASTILLO, A. O maricas. Lampiăo da Esquina. Rio de Janeiro, nº 3, ago. 1978, Seçâo literária.

DANIEL, H. Passagem para o próximo sonho: um possível romance autocrítico. Editora Codecri, 1982.

DELEUZE, G. Michel Foucault: as formaçōes históricas. Sāo Paulo: N-1 ediçôes; Politeia, 2017.

EAGLETON, T. Teoria da literatura: uma introduçăo. Săo Paulo: Martins Fontes, 2003. ECO, U. O Fascismo Eterno. In: Cinco escritos morais. Rio de Janeiro: Record, 2002.

FOUCAULT, M. A coragem da verdade: o governo de si e de outros II: curso no Collège de France (1983-1984). Sâo Paulo: Martins Fontes, 2011. 
FOUCAULT, M. A sociedade punitiva: curso no Collège de France (1972 -1973); Traduçăo Ivone C. Benedetti. Sáo Paulo: Martins Fontes, 2015.

FOUCAULT, M. História da Sexualidade 1: a vontade de saber. Rio de Janeiro: Paz e Terra, 2017.

GALEANO, E. El derecho al delirio. In: GALEANO, E. Patas arriba: la escuela del mundo al revés. Madrid: Siglo XXI, 1998.

GREEN, J. Além do carnaval: a homossexualidade masculina no Brasil do século XX. Săo Paulo: UNESP, 2000.

GROS, F. A parrhesia em Foucault (1982-1984). In: GROS, F. et al (Orgs.). Foucault: a coragem da verdade. Trad. Marcos Marcionilo. Sáo Paulo: Parábola, 2004.

HILÁRIO, P. A dona boazuda. Lampiāo da Esquina. Rio de Janeiro, nº 4, out. 1978, Seçâo literária.

HOCQUENGHEM, G. A contestaçăo homossexual. Săo Paulo: Brasiliense, 1980.

JORGE, F. Antropofagia. Lampiăo da Esquina. Rio de Janeiro, nº 0, abr. 1978, Seçăo literária. LAGAZZI, S. 0 desafio de dizer năo. Campinas, SP: Pontes, 1988.

LENTIN, R. Femina sacra: Gendered memory and political violence. Women's Studies International Forum. Pergamon, p. 463-473, 2006.

LOPES, D. O homem que amava rapazes e outros ensaios. Rio de Janeiro: Aeroplano, 2002. MAFFESOLI, M. Homossociabilidade: da identidade às identificaçôes. Bagoas Revista de Estudos Gays e Lésbicos, Natal, v. 1, n. ${ }^{\circ}$, p. 15-26, 2012.

MAFFESOLI, M. No fundo das aparências. Petrópolis: Vozes, 1996.

MAFFESOLI, M. O instante eterno. Sáo Paulo: Zouk, 2003.

MAFFESOLI, M. 0 tempo das tribos: o declínio do individualismo nas sociedades de massa. Săo Paulo: Forense-Universitária, 1987.

MELO, I. M; BECK, M. Auscultar vestígios: a especificidade significante do silêncio na divisăo do trabalho semântico. In: Anais do IX Seminário de Estudos em Análise do Discurso (SEAD). Recife, 2019a. Disponível em: http://anaisdosead.com.br/9SEAD/ SIMPOSIOS/S3_MauricioBeckelagoMouraMelo.pdf Acesso em: 08 de maio de 2020.

MELO, I. M.; BECK, M. Vestígios do silêncio. RUA, v. 25, n. 1, 2019b.

MÍCCOLIS, L. O poema para teus seios. Lampiăo da Esquina. Rio de Janeiro, nº 0, abr. 1978, Seçăo literária.

MORANDO, L. Por baixo dos panos: repressâo a gays e travestis em Belo Horizonte (19631969). In: GREEN, J; QUINALHA, R. (Org.). Ditadura e homossexualidades: repressăo, resistência e a busca da verdade. Săo Carlos: EduFSCar, 2015, p. 53-82.

MOURA, M. de. Aniversário. Lampiăo da Esquina. Rio de Janeiro, nº 0, abr. 1978, Seçâo literária, p. 16.

NIETZSCHE, F. O nascimento da tragédia: ou helenismo e pessimismo. Editora Companhia das Letras, 2007.

PAGLIA, C.Personas sexuais: arte e decadência de Nefertite a Emily Dickinson. Companhia das Letras, 1990. 
PEDRÓS GASCÓN, A. F. España, laberinto de soledades: latinoamericanización del imaginario nacional en "Tiempo de silencio" y "Reivindicación del conde don Julián”. España contemporánea: Revista de literatura y cultura, Barcelona, v. 20, n. 1, p. 39-62, 2007.

PEREIRA, T.; MITIDIERI, A. Com o falo na boca: artivismo literário. Litterata: Revista do Centro de Estudos Portugueses Hélio Simóes, v. 8, n. 1, p. 183-199, 2018.

PESAVENTO, S. J. Este mundo verdadeiro das coisas de mentira: entre a arte e a história. Revista Estudos Históricos, Sáo Paulo, v. 2, n. 30, p. 56-75, 2002.

PUIG, M. Trechos do romance $O$ beijo da mulher aranha. Lampiăo da Esquina. Rio de Janeiro, nº 6, dez. 1978, Seçâo literária.

RAPISARDI, F; MODARELLI, A. Fiestas, baños y exilios: los gays porteños en la última dictadura. Buenos Aires: Sudamericana, 2001.

RIOS, C. A hora do amor. Lampiăo da Esquina. Rio de Janeiro, nº 5, nov. 1978, Seçăo literária.

ROCHA, M. Do outro lado da porta. Lampiăo da Esquina. Rio de Janeiro, nº 2, maio 1978, Seção literária.

ROIG, A. Nem todos os parques săo um paraíso. Lampiăo da Esquina, Rio de Janeiro, $n^{0} 1$, abr. 1978, Seçăo literária.

SANTOS, R. Cassandra Rios e o surgimento da literatura gay e lésbica no Brasil. Revista Gênero, v. 4, n. 1, 2012.

SIMAKAWA, V. V. Por inflexóes decoloniais de corpos e identidades de gênero inconformes: uma análise autoetnográfica da cisgeneridade como normatividade. Dissertaçâo (Mestrado em Cultura e Sociedade) - Universidade Federal da Bahia, Salvador, 2015.

TREVISAN, J. S. Devassos no paraíso: A homossexualidade no Brasil, da colônia à atualidade. Rio de Janeiro: Objetiva, 2018.

VIDARTE, Paco. Ética bixa: proclamaçōes libertárias para uma militância LGBTQ. Sâo Paulo: N-1 ediçóes, 2019.

WARAT, L. A. Manifesto do surrealismo jurídico. Santa Catarina: Acadêmica, 1988.

ZIAREK, E. P. Bare life on strike: Notes on the biopolitics of race and gender. South Atlantic Quarterly, v. 107, n. 1, p. 89-105, 2008. 